\title{
Two new species of Handroanthus Mattos (Bignoniaceae) from the state of Bahia, Brazil
}

Fabio da Silva do Espírito Santo ${ }^{1,3}$, Milene Maria da Silva-Castro ${ }^{2}$ and Alessandro Rapini ${ }^{1}$

Recebido em 2/02/2012. Aceito em 5/06/2012

\section{RESUMO}

(Duas novas espécies de Handroanthus Mattos (Bignoniaceae) para o estado da Bahia, Brasil) Duas novas espécies de Handroanthus Mattos (Bignoniaceae), endêmicas da Floresta Estacional Semidecidual da Bahia, são aqui descritas sob o nome de H. diamantinensis e H. parviflorus. São apresentadas ilustrações, mapa de distribuição, bem como uma discussão sobre as diferenças morfológicas que distinguem tais espécies daquelas mais relacionadas.

Palavras-chave: Floresta Estacional Semidecidual, ipê, Nordeste, taxonomia

\begin{abstract}
(Two new species of Handroanthus Mattos (Bignoniaceae) from the state of Bahia, Brazil). Two new species of Handroanthus Mattos (Bignoniaceae), endemic to Semideciduous Seasonal Forest of Bahia, are here described as $H$. diamantinensis and H. parviflorus. Illustrations, distribution maps, as well as a discussion about the morphological characteristics that distinguish the new species from related species are presented.
\end{abstract}

Key words: Semideciduous Seasonal Forest, Northeastern Brazil, ipê, taxonomy

\section{Introduction}

Bignoniaceae have a Pantropical distribution and are most diverse in the Neotropics, especially South America (Gentry 1980; Lohmann 2004). The family comprises 82 genera and approximately 827 species (Lohmann \& Ulloa 2007), and is currently divided into seven clades (Bignonieae, Catalpeae, Oroxyleae, Crescentiina, Tecomeae, Tourrettieae, and Jacarandeae; Olmstead et al. 2009). Crescentiina is composed of two "subclades", one exclusively Paleotropical and the other Neotropical, comprising several species traditionally included in Tecomeae. The Neotropical "subclade" contains 14 genera and 147 species, and has been given the informal name " $\mathrm{Ta}$ bebuia Alliance" due to the high number of Tabebuia species (Grose \& Olmstead 2007a; Olmstead et al. 2009) that together with Handroanthus represent about $66 \%$ of the species within the group (Grose \& Olmstead 2007b).

Handroanthus displays ample morphological variability. Species in the genus have the following characteristics: an arboreal or occasionally shrubby habit; palmately compound leaves that are (3-)5-9-foliolate (rarely 1 -foliolate), with simple and / or branched trichomes; inflorescences that are dichotomously branched, with poorly developed rachises many times contracted and covered in simple, stellate, or dendroid trichomes; a calyx that is coriaceous, campanulate, and mostly 5-lobed, with indumentum also composed of simple, stellate or dendroid trichomes; a corolla that is predominantly yellow (lilac in only four species), tubular-infundibuliform to tubular-campanulate, with a glabrous or tomentose internal surface; fruits that are capsular, linear-cylindrical, smooth to slightly ribbed, pubescent, glabrous or sparse-lepidote; and seeds that are bi-winged, with wings clearly demarcated from the seminiferous body. The genus comprises 30 species and is widely distributed in Central and South America, with one species, H. billbergii, (Bureau \& K.Schum.) S.O.Grose occurring in the Antilles (Grose \& Olmstead 2007b).

While working on the taxonomic treatment of the " $\mathrm{Ta}$ bebuia Alliance" for the flora of Bahia State, Brazil, two new species of Handroanthus were found. These taxa are here described as $H$. diamantinensis and $H$. parviflorus.

\footnotetext{
${ }^{1}$ Universidade Estadual de Feira de Santana, Departamento de Ciências Biológicas, Feira de Santana, Bahia, Brazil

${ }^{2}$ Universidade Estadual do Sudoeste da Bahia, Departamento de Ciências Biológicas, Jequié, Bahia, Brazil

${ }^{3}$ Author for correspondence: fabiounivasf@yahoo.com.br
} 


\section{Taxonomic treatment}

\author{
Handroanthus diamantinensis Espírito-Santo \& M.M. \\ Silva-Castro, sp. nov.
}

Fig. 1; 3: A-D.

Handroanthus diamantinensis is similar to H. botelhensis (A.H. Gentry) S.O. Grose, differing due to the strongly discolorous leaflets ( $v$ s. concolorous to weakly discolorous) when adult, opening of floral tube $2.8-4.1 \mathrm{~cm}(v \mathrm{~s} .2-2.5 \mathrm{~cm})$ wide, villous region of stamen insertion (vs. glabrous) and capsules $39.3-66.0 \times 1.5-2.3 \mathrm{~cm}$ (vs. $21-23 \times 1.3-1.4 \mathrm{~cm})$.

Tree up to $30 \mathrm{~m}$ high; branches cylindrical to subtetragonal, slightly fissured longitudinally, pubescent, trichomes stellate and dendroid up to $2 \mathrm{~mm}$ long. Leaves 5(6)7-foliolate; petiole $11.8-32.4 \mathrm{~cm}$ long, cylindrical, densely tomentose, trichomes stellate and dendroid; central petiolule $3.4-14.6 \mathrm{~cm}$ long, densely tomentose, trichomes stellate and dendroid; leaflets $12.2-30.8 \times 4.6-17.3 \mathrm{~cm}$, elliptic to oblong-elliptic, base truncate, rounded or obcordate, apex acute to acuminate, margin entire, coriaceous, strongly discolorous, adaxial surface olive-green, glabrescent, with trichomes restricted to the main and secondary veins, abaxial surface cream-yellow, densely tomentose, with stellate and dendroid trichomes covering the whole surface; when young: membranous, margin sometimes irregularly serrated from the middle apical region, adaxial surface moss-green, abaxial surface cream-ferruginous, tomentose in both surfaces, trichomes stellate and dendroid; petiolules and leaflets progressively smaller towards the extremities. Inflorescences open panicles c. $30 \times 20 \mathrm{~cm}$, terminal; peduncle densely tomentose, trichomes dendroid; bracts and bracteoles $0.3-0.5 \mathrm{~cm}$ long, lanceolate, persistent. Flowers with pedicel c. $2.5 \mathrm{~cm}$ long; calyx $1.9-2.9 \times 1-1.6$ $\mathrm{cm}$, tubular, brownish-ferruginous, 2-3-lobed, irregularly partite, apex obtuse, densely villous, dendroid trichomes to $1.5 \mathrm{~mm}$ long, and also stellate trichomes; corolla tubularinfundibuliform, $8-8.8 \mathrm{~cm}$ long, floral tube $4.1-5.5 \mathrm{~cm}$ long, opening $2.8-4.1 \mathrm{~cm}$ wide, lobes $1.5-2.8 \mathrm{~cm}$ long, yellow, with reddish striations, base fleshy and apex membranous, externally densely glandular, internally villous, trichomes simple; stamens inserted, free part of the dorsal stamens $\mathrm{c}$. $1.2 \mathrm{~cm}$ long, free part of the ventral stamens c. $1.6 \mathrm{~cm}$ long, free part glabrous, adnate part tomentose, anthers glabrous, thecae c. $2.5 \times 1 \mathrm{~mm}$; ovary c. $8 \times 3 \mathrm{~mm}$, linear-oblong, not ribbed, minutely lepidote-glandular; nectarial disk annular, conspicuous; style c. $2.3 \mathrm{~cm}$ long, glabrous, stigma c. $2.5 \mathrm{~mm}$ long, glabrous, bifid. Capsules 39.3-66×1.5-2.3 cm, linearcylindrical, brownish-ferruginous, longitudinally striated, densely tomentose, trichomes dendroid. [Seeds not seen].

Type: BRAZIL. Bahia: Palmeiras, Chapada Diamantina National Park, Vale do Pati, Mucugê-Andaraí trail

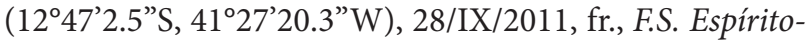
-Santo \& G.B. Siqueira 189 (holotype HUEFS; isotype RB).
Epitype: BRAZIL. Bahia: Palmeiras, Chapada Diamantina National Park, Vale do Pati, Mucugê-Andaraí trail (1247’2.5”S, 41²7’20.3”W), 20/VIII/2010, fl., F.S. Espírito-Santo et al. 138 (HUEFS).

Distribution, habitat, and conservation status - Handroanthus diamantinensis is restricted to Semideciduous Seasonal Forest in the Chapada Diamantina (Fig. 4), and is known only from the Vale do Pati, a valley with a trekking path of approximately $80 \mathrm{~km}$ that links the municipalities of Mucugê and Andaraí, traversing the Chapada Diamantina National Park, Bahia. In spite that the area is in a good conservation state and is legally protected, less than 10 individuals of the new species were located in the field. Considering the conspicuous flowering of the whole group, it can be inferred that the species has a punctual distribution and occurs in low frequency in the area. On the other hand, collection efforts at this locality are not intensive, and the flora is still poorly known. Since the species was collected only recently, and its only record is within a protected area, it is still premature to classify it at any level of threat. Thus, the species should be considered as Data Deficient (DD; IUCN 2001) for the assessment of its conservation status.

Etymology - The epithet refers to the area where this species occurs, which is the Chapada Diamantina, in Bahia, Brazil.

Notes - In the taxonomic treatment of tribe Tecomeae for the Neotropical region, Gentry (1992) informally subdivided Tabebuia s.l. into ten groups using vegetative and reproductive characters. Handroanthus diamantinensis is more closely related to group IV, characterized by the yellow flowers with a calyx that is densely pubescent or occasionally villous, with stellate or dendroid trichomes; leaflets with few trichomes restricted to the main vein on the abaxial surface or, more frequently, densely distributed on the whole surface; and capsules that are puberulous or villous, and covered with stellate or dendroid trichomes. Among the species of this group, $H$. diamantinensis is most similar to $H$. botelhensis, but also has morphological similarities with $H$. albus (Cham.) Mattos, $H$. vellosoi (Toledo) Mattos, and H. catarinensis (A.H.Gentry) S.O.Grose (Tab. 1). It differs from $H$. botelhensis due to the strongly discolorous leaflets of adult plants ( $v s$. concolorous to weakly discolorous), calyx 2-3-lobed (vs. 2-5-lobed), longer corolla $(8-8.8 v s .6-8 \mathrm{~cm})$, larger opening of the floral tube $(2.8-4.1$ vs. $2-2.5 \mathrm{~cm})$, tomentose region of stamen insertion (vs. glabrous), and the bigger capsules $(39.3-66 \times 1.5-2.3 \mathrm{~cm}$ vs. $21-23 \times 1.3-1.4 \mathrm{~cm})$. Handroanthus diamantinensis can be promptly distinguished from the remaining mentioned species due to the entire margins of mature leaflets ( $v s$. regular and conspicuously serrated), among other characters (Tab. 1). The epitype was designated to help with the species interpretation because the type lacks flowers. 


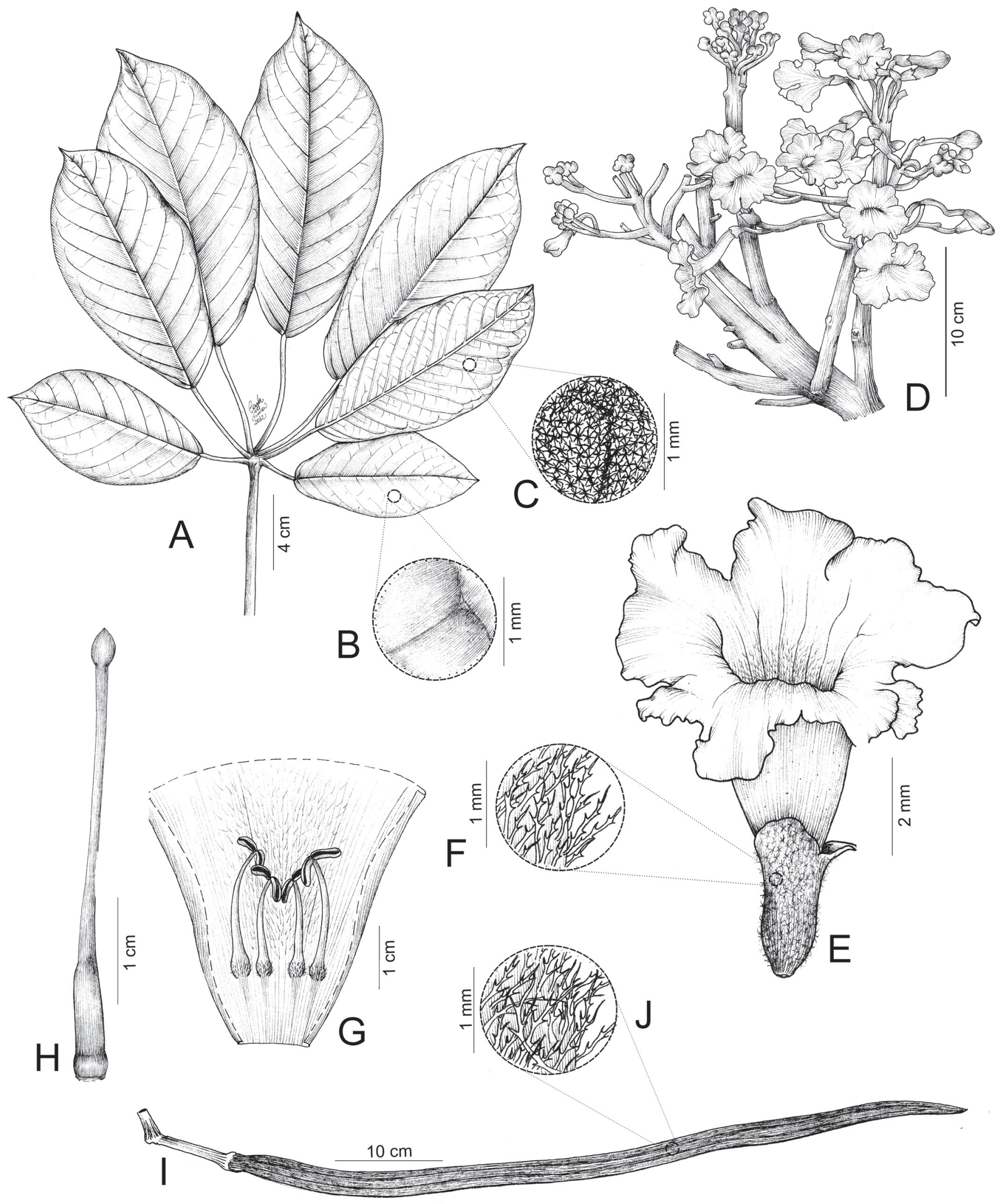

Figure 1. Handroanthus diamantinensis Espírito-Santo \& M.M.Silva-Castro. A. Leaf. B. Indumentum of adaxial surface; C. Indumentum of abaxial surface; D. Inflorescence; E. Flower; F. Indumentum of calyx; G. Open corolla, showing the stamens; H. Gynoecium; I. Capsule; and J. Indumentum of capsule. (From the holotype) 
Table 1. Comparison of diagnostic morphological characters of Handroanthus diamantinensis Espírito-Santo \& M.M.Silva-Castro with its most closely related species, according to the informal division of Tabebuia s.l. proposed by Gentry (1992).

\begin{tabular}{|c|c|c|c|c|c|c|c|c|c|c|c|}
\hline \multirow[b]{2}{*}{$\begin{array}{l}\text { Handroanthus } \\
\text { species }\end{array}$} & \multirow[b]{2}{*}{ Habit } & \multicolumn{2}{|c|}{ Leaflets } & \multirow[b]{2}{*}{ Inflorescence } & \multicolumn{2}{|c|}{ Calyx } & \multicolumn{3}{|c|}{ Corolla } & \multicolumn{2}{|c|}{ Capsules } \\
\hline & & Margin & Color & & $\begin{array}{l}\mathrm{N}^{\circ} \text { of } \\
\text { lobes }\end{array}$ & $\begin{array}{l}\text { Type of } \\
\text { trichome }\end{array}$ & $\begin{array}{l}\text { Length } \\
(\mathrm{cm})\end{array}$ & $\begin{array}{l}\text { Opening } \\
\text { of floral } \\
\text { tube }(\mathrm{cm})\end{array}$ & $\begin{array}{c}\text { Region of } \\
\text { insertion of } \\
\text { stamens }\end{array}$ & $\begin{array}{c}\text { Size }(\mathrm{cm}) \text { : } \\
\text { length } \times \\
\text { width }\end{array}$ & $\begin{array}{l}\text { Type of } \\
\text { trichome }\end{array}$ \\
\hline H. diamantinensis & Arboreal & Entire & $\begin{array}{c}\text { Strongly } \\
\text { discolorous }\end{array}$ & Open panicle & 2 or 3 & $\begin{array}{l}\text { Dendroid } \\
\text { and stellate }\end{array}$ & $8-8.8$ & $2.8-4.1$ & Villous & $\begin{array}{c}39.3-66 \times \\
1.5-2.3\end{array}$ & Dendroid \\
\hline H. albus & Arboreal & Serrated & $\begin{array}{c}\text { Strongly } \\
\text { discolorous }\end{array}$ & Open panicle & 5 & Dendroid & $6-18$ & $1.5-3.0$ & - & $\begin{array}{c}25-50 \times \\
1-1.7\end{array}$ & Dendroid \\
\hline H. botelhensis & Arboreal & Entire & $\begin{array}{l}\text { Concolorous } \\
\text { or weakly } \\
\text { discolorous }\end{array}$ & Open panicle & $2-5$ & $\begin{array}{c}\text { Barbate, } \\
\text { dendroid } \\
\text { and stellate }\end{array}$ & $6-8$ & $2-2.5$ & Glabrous & $\begin{array}{c}21-23 \times \\
1.3-1.4\end{array}$ & $\begin{array}{l}\text { Mostly } \\
\text { barbate }\end{array}$ \\
\hline H. catarinensis & Shrubby & Serrated & Concolorous & $\begin{array}{l}\text { Contracted } \\
\text { panicle }\end{array}$ & $3-5$ & Barbate & $5-7$ & $1.4-2.2$ & Glabrescent & $\begin{array}{c}5-9 \times \\
1.5-1.8\end{array}$ & $\begin{array}{l}\text { Mostly } \\
\text { barbate }\end{array}$ \\
\hline H. vellosoi & $\begin{array}{l}\text { Shrubby/ } \\
\text { Arboreal }\end{array}$ & Serrated & $\begin{array}{c}\text { Strongly } \\
\text { discolorous }\end{array}$ & $\begin{array}{l}\text { Contracted } \\
\text { panicle }\end{array}$ & $2-5$ & $\begin{array}{l}\text { Simple and } \\
\text { stellate }\end{array}$ & $5-8$ & $1.5-2.5$ & Glabrous & $\begin{array}{c}10-40 \times \\
1.3-1.5\end{array}$ & $\begin{array}{l}\text { Stellate } \\
\text { and } \\
\text { simple }\end{array}$ \\
\hline
\end{tabular}

Handroanthus parviflorus Espírito-Santo \& M.M. Silva-Castro, sp. nov.

Fig. 2; 3: E-F.

Handroanthus parviflorus is similar to H. spongiosus (Rizzini) S.O.Grose but differ due to the leaves (3-)5(-7)-foliolate (vs. 3-foliolate), lepidote leaflets (vs. stellate-tomentose), with acute apex ( $v$ s. attenuate to cuspidate), sessile to subsessileflowers (vs. pedicellate), calyx 2-3-lobed (vs. 5-lobed), and region of stamen insertion pilose (vs. glabrous). The species possess the smallest flowers recorded so far in Handroanthus.

Tree up to $12 \mathrm{~m}$ high; branches cylindrical, longitudinally fissured, pubescent, trichomes simple and stellate. Leaves (3-)5(-7)-foliolate; petiole 2.2-6.7 cm long, cylindric to subtetragonal, pubescent, trichomes simple and stellate; central petiolule $0.8-2.1 \mathrm{~cm}$ long, pubescent, trichomes simple and stellate; central leaflets 5.2-12.7 $\times$ $2-4.4 \mathrm{~cm}$, elliptic, base cuneate, apex acute, margin entire, flat, membranous to chartaceous, concolorous, adaxial surface sparsely lepidote, with main and secondary veins densely tomentose, trichomes stellate, abaxial surface lepidote, few stellate trichomes sparsely dispersed in both surfaces; petiolules and leaflets progressively smaller towards the extremities. Inflorescences glomerulate, terminal, few-flowered; peduncle rather reduced, smaller than $4 \mathrm{~mm}$ long, stellate-tomentose; bracts and bracteoles absent. Flowers sessile or subsessile; calyx $0.5-0.6 \times$ $0.3-0.5 \mathrm{~cm}$, campanulate, 2-3-lobed, irregularly partite, apex cuneate to rounded, densely tomentose, trichomes stellate, ferruginous; corolla tubular-infundibuliform $2.2-3.2 \mathrm{~cm}$ long, flower tube $1.7-2.3 \mathrm{~cm}$ long, opening $0.8-1.2 \mathrm{~cm}$ wide, lobes $0.6-0.8 \mathrm{~cm}$ long, yellow, with reddish striation in the face, externally glabrous, internally densely villous; stamens inserted, free part of the dorsal stamens c. $0.6 \mathrm{~cm}$ long, free part of the ventral stamens c. $1.2 \mathrm{~cm}$ long, free part glabrous, adnate part villous, anthers glabrous, thecae c. $1.5 \times 1 \mathrm{~mm}$; ovary c. $4.0 \times$ $1.5 \mathrm{~mm}$, ovoid-oblong, lepidote-glandular; nectarial disk annular, conspicuous; style $1.4-1.5 \mathrm{~cm}$ long, glabrous, stigma c. $1.5 \mathrm{~mm}$ long, glabrous, bifid. Capsules c. 20.6 $\times 1.1 \mathrm{~cm}$, linear-cylindrical, brownish, not ribbed, glabrescent. Nucleus seminiferous c. $0.4 \times 0.6 \mathrm{~cm}$, elliptic; wings c. $0.6 \mathrm{~cm}$ long.

Type: BRAZIL. Bahia: Itapé, road from Itapé to Itaju do Colônia, in a branch $19,7 \mathrm{~km}$ from the exit of Itaju do Colônia (1457'37”S, 39³6'35”W), 27/X/2004, fl., A.M.A. Amorim et al. 4323 (holotype CEPEC, isotype SPF).

Paratype: BRAZIL. Bahia: Itapé, road from Itapé to Itaju do Colônia, in a branch $19,7 \mathrm{~km}$ from the exit of Itaju do Colônia ( $\left(4^{\circ} 57^{\prime} 37^{\prime \prime}\right.$ 'S, 39³6'35”W), 08/XII/2011, fr., F.S. Espirito-Santo et al. 190 (CEPEC, HUEFS, SPF).

Distribution, habitat, and conservation status - Handroanthus parviflorus is known from a single location in Semideciduous Seasonal Forest, in the municipality of Itapé, in the state of Bahia (Fig. 4). The area is in an advanced stage of degradation, which is especially due to agriculture and cattle farming; the original vegetation is rather impoverished and reduced to small patches. Therefore, according to the criteria proposed by the IUCN (2001), H. parviflorus should be classified as Endangered [EN B1ab(iii) + D1].

Etymology - The epithet refers to the reduced dimensions of floral characters in this species.

Notes - As with $H$. diamantinensis, $H$. parviflorus would also be positioned within group IV proposed by Gentry (1992), and displays floral characters that are only similar to H. spongiosus. Handroanthus parviflorus can be distinguished from $H$. spongiosus, a species endemic 


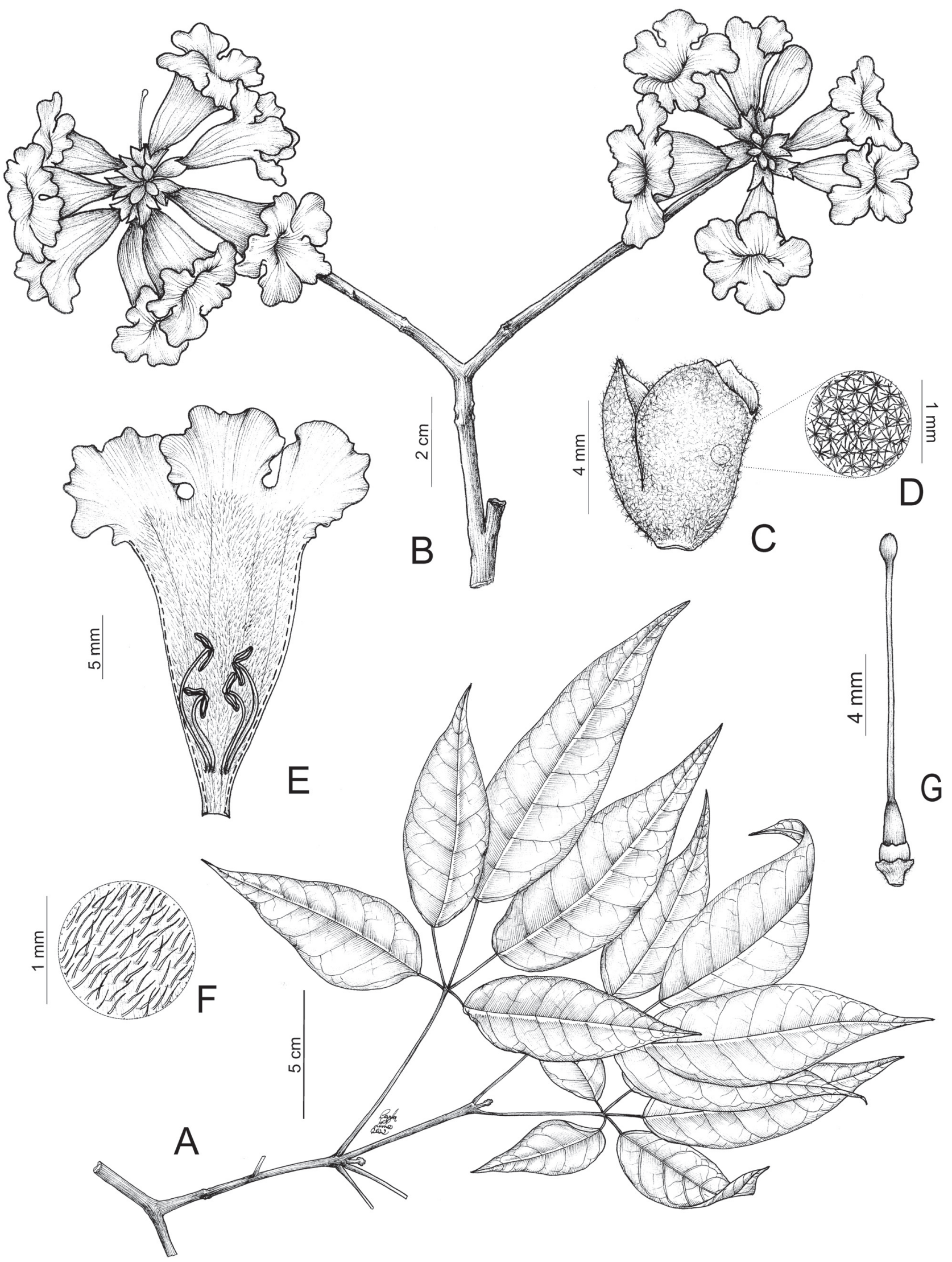

Figure 2. Handroanthus parviflorus Espírito-Santo \& M.M.Silva-Castro. A. Branch with leaves; B. Flowering branch; C. Calyx; D. Indumentum of calyx; E. Open corolla, showing the stamens; F. Indumentum of internal surface of corolla; and G. Gynoecium. (A. F.S. Espirito-Santo et al. 190; B-G. A.M.A. Amorim et al. 4323) 

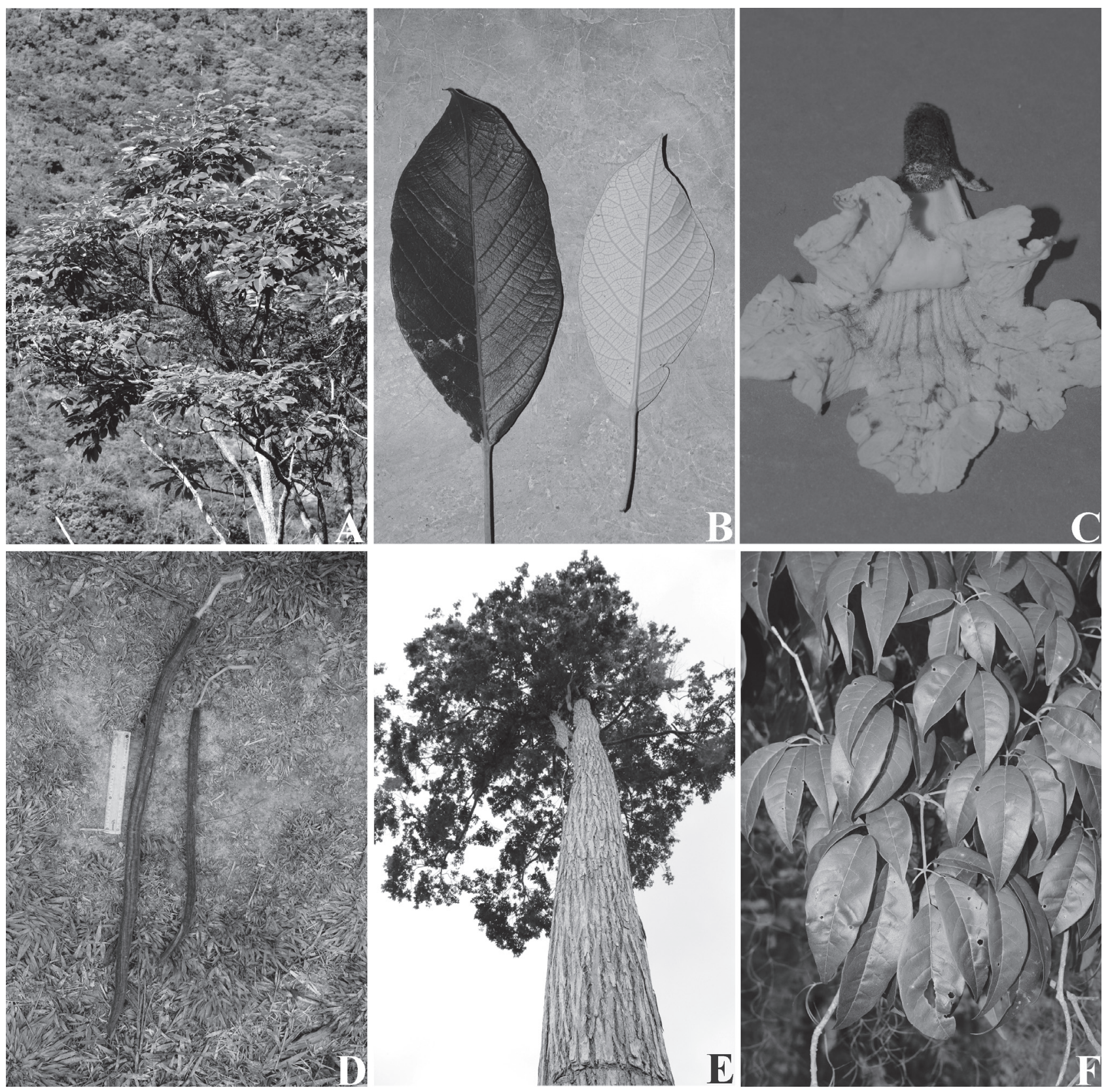

Figure 3. A-D. Handroanthus diamantinensis Espírito-Santo \& M.M.Silva-Castro, municipality of Palmeiras, Chapada Diamantina National Park, state of Bahia, Brazil. A. Habit; B. discolorous leaflets; C. Flower; D. Capsules. E-F. Handroanthus parviflorus Espírito-Santo \& M.M.Silva-Castro, municipality of Itapé, Bahia, Brazil. E. Habit; F. Leaves. (Photos by FSES)

to the caatinga dry forest, due to the sessile to subsessile flowers ( $v s$. pedicellate), calyx 2-3-lobed ( $v s .5$-lobed), acute to rounded apex of lobes ( $v s$. mucronate) and pilose region of stamen insertion (vs. glabrous). Additionally, $H$. parviflorus generally has smaller flowers than $H$. spongiosus (corolla 2.2-3.2 vs. 2.5-4.2 cm long, with tube $1.7-2.3$ vs. $2-3 \mathrm{~cm}$ long), a trunk with rhytidome not detaching in long longitudinal strips, and leaves that are $(3-) 5(-7)$-foliolate ( $v s$. always 3 -foliolate), lepidote ( $v s$. stellate-tomentose), with leaflets with acute ( $v s$. attenuate to cuspidate) apex.

\section{Acknowledgements}

We thank Dr. André M.A. Amorim and staff (CEPEC) for the logistical support during the collecting trips in southern Bahia; Gabriela B. Siqueira (UEFS), Luciano G.P. de Almeida Aguiar (UEFS), Paulo Ricardo M. de Almeida (UEFS), and Thalison Ribeiro for their help during the field trips; IBAMA for the collection license (n. 27449-1); Fapesb for supporting the project Flora of Bahia; and CNPq for granting a master's degree scholarship to the first author and a productivity grant (PQ-2) to AR. 


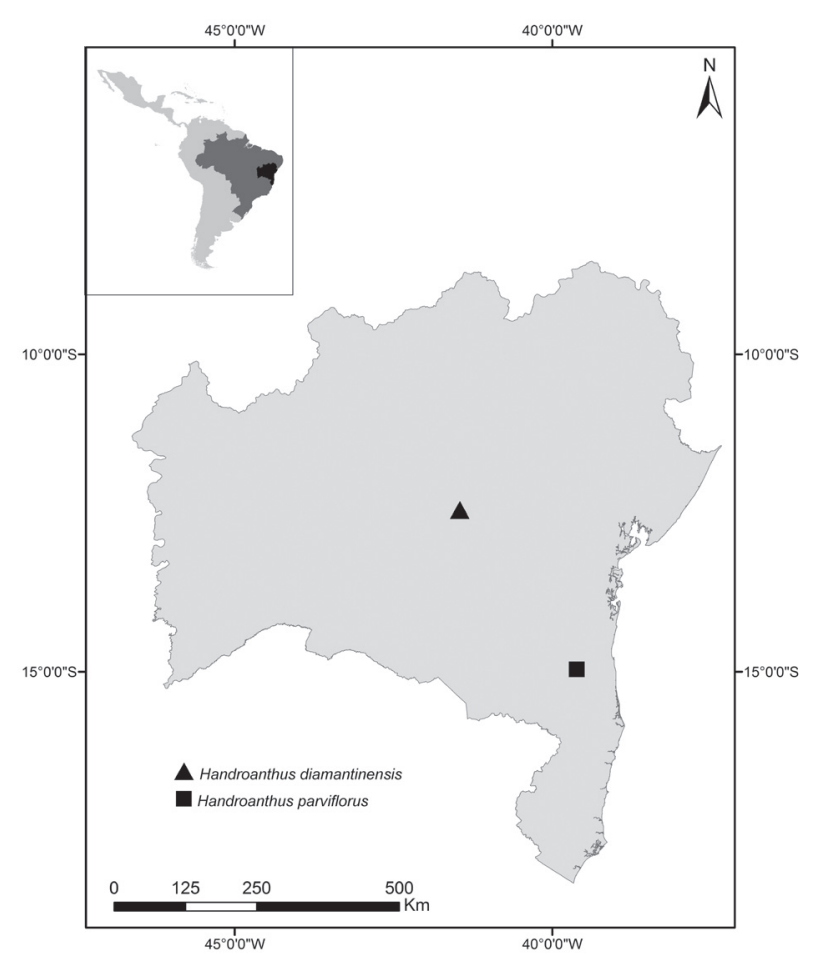

Figure 4. Map indicating the locations of Handroanthus diamantinensis Espírito-Santo \& M.M. Silva-Castro, municipality of Palmeiras, and H. parviflorus Espírito-Santo \& M.M. Silva-Castro, municipality of Itapé, Bahia, Brazil.

\section{References}

Gentry, A.H. 1980. Bignoniaceae, Part I. Tribes Crescentieae and Tourrettieae. Flora Neotropica Monograph 25: 1-130.

Gentry, A.H. 1992. Bignoniaceae. Part II. Tribe Tecomeae. Flora Neotropica 25: 1-362.

Grose, S.O. \& Olmstead, R.G. 2007a. Evolution of a charismatic neotropical tree: molecular phylogeny of Tabebuia s. 1., and allied genera (Bignoniaceae). Systematic Botany 32: 650-659.

Grose, S.O. \& Olmstead, R.G. 2007b. Taxonomic revisions in the polyphyletic genus Tabebuia s. 1. (Bignoniaceae). Systematic Botany 32: 660-670.

IUCN. 2001. IUCN Red List Categories and Criteria. Version 3.1. Gland, Switzerland \& Cambridge, UK, IUCN Species Survival Commission.

Lohmann, L.G. 2004. Bignoniaceae. Pp. 51-53. In: Smith, N.; Mori, S.A.; Henderson, A.; Stevenson, D.Wm. \& Heald, S.V. Flowering plants of the Neotropics. Princepton, Princepton University Press.

Lohmann, L.G. \& Ulloa, C.U. 2007. Bignoniaceae. In: iPlants prototype checklist. Disponível em: http://www.iplants.org (Accessed 10 Aug. 2011)

Olmstead, R.G.; Zjhra, M.L.; Lohmann L.G.; Grose, S.O. \& Eckert, A.J. 2009. A molecular phylogeny and classification of Bignoniaceae. American Journal of Botany 96(9): 1731-1743. 